Scales very strongly ctenoid, present everywhere except on top of head, swout, breast, and a very narrow streak in front of dorsal. Lateral line with a rather weak arch anteriorly, the pores continuing on 20 or 21 scales, discontinued about under base of last dorsal spine.

Two specimens (probably males) were picked out of the mud in the bag of the seine.

Indiana University, May 10, 1884.

\title{
REMARKS ON THE SPECIES OF THE GENUS CEPPHUS.
}

BY LEONHADB STEJNEGER.

The following papers were originally prepared for publication separately. When the last one was finished they were found to constitute a kind of monograph of the genus Cepphus, and it was therefore thought more useful to have them published together under one heading. The occasional repetitions are thus accounted for.

For the sake of completeness, the synonymy of the generic name is here added.

\section{Cepphus Pallas.}

< 1758.-Alea Lrn., Syst. Nat., 10 ed., I, p. 130.

$<1760 .-$ Uria Briss., Orn. VI, p. 70.

$<$ 1766.-Colymbus Lin., Syst. Nat., 12 ed., I, p. 220.

$<$ 1769.-Cepphus Pall., Spic. Zool., V, p. 33 (type C. lacteolus).

$=$ 1819._Grylle Leach, in Ross's Voy. Discov. N. W. Pass., App., p. LI (type G. scapularis LEACH).

\section{I.-C'epphus MOTZFELdi (BENICKEN).}

I wish to call the attention of ornithologists, and especially those in North America, to the fact that, in all probability, a black-winged Guillemot occurs in the North Atlantic, having mostly been orerlooked or regarded as a melanotic phase of the Common Guillemot since its first discovery sixty years ago. It would be exceedingly interesting to ascertain the status of the alleged species, a question of special concern to American ornithologists since the type was received from Greenland.

The information at hand is very scanty and the sources of rather difficult access to many ornithologists; even Prof. A. Newton failed in finding one of the original descriptions. I therefore intend to give in the following a complete extract of all that has been written about the matter, as far as it is known and accessible to me, believing that such a bringing together of all the material may facilitate the work of future investigators, and hoping that it may stimulate to further research when it is seen how little is knowu ahout a bird inhabiting the seas between North America and Europe.

In a paper entitled "Beyträge zur nordisehen Ornithologie" (=Contributions to Northern Ornithology) and published in the August num- 
ber of Oken's Isis, 1824 (pp. 877-891), Mr. Benicken described a new Guillemot in the following words):

$$
\text { [p. 888] Uria. }
$$

"Although convinced that great discretion is to be exercised in establishing new species, particularly among the northern water birds, in which the different species of each genus are so very much alike in regard to coloration, while even the different individuals of the same species, according to circumstances, vary greatly in size and shape of bill, etc., I am inclined to think that, besides the known species of Uria, still a new one occurs in the polar seas, which, although on the whole resembling the allied forms, differs distinctly from every one of them. The length of the bird is 16 inches 9 lines, Hamburg measure [ $=400 \mathrm{~mm} *$ ]. Bill black, much compressed, with very prominent edges of the upper mandible, a strongly-marked gonydeal protuberance, bent tip, and feathered as far as above the nostrils.

"Length of bill from forehead ................... inch, 9 lines H. m. [42mm

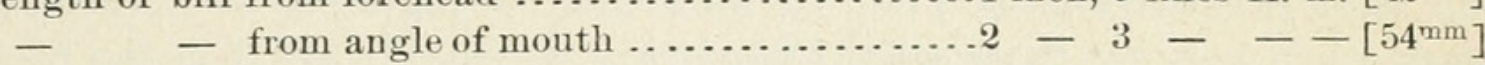

- $\quad-$ from nostrils .................... - $-\left[24^{\mathrm{mm}}\right]$

Length of head from nape to forehead..............2 - $-\left[48^{\mathrm{mm}}\right]$

Length of head including the bill .................. $\left.3-9--\frac{9}{90^{\mathrm{mm}}}\right]$

"Tarsus 1 inch 6 lines [36 mm], yellowish brown. The webs whitish. The entire plumage sooty black, on the abdomen shading somewhat into grayish; wingfeathers brownish black.

"From this description it is plain that the bird in question is distinguished from $U$. grylle by being of larger size, from $U$. troile and Briinnichii by having a differently shaped bill. The latter is much shorter and more compressed than in $U$.troile, in shape resembling more that of $U$. Briinnichii, but is shorter and only one-third as broad.

"I am unable to say more about this bird, as I only received one single skin in 1820. Mr. Faber, who in Iceland had ample opportunities for studying the known Guillemots, declares it to be a new species. Should other ornithologists agree herein and allow me, as the first describer of the species, to apply a name to it [p. 889)] I should wish to have it named Uria Motzfeldi, after a friend of mine to whom I am indebted for many a northern curiosity."

In the following, the September, number of the same journal, Faber, in the third part of his excellent "Beyträge zur arctischen Zoologie" (Contributions to Arctic Zoology), treating monographically of the genus Uria (=Cepphus + Uria), on page 981, describes the same specimen as new under the name of [p. 981]

\section{"7. Uria unicolor.}

"By this name I wish to call theattention of ornithologists to a very rare Guillemot found in the northern bird-rookeries. I will here present my data, learing it to later experience to decide whether it is a new species or not. The owner of the bird-rookery on Drangöe- [Iceland]

\footnotetext{
${ }^{*}$ One inch Hamburg measure $=0.0239^{\mathrm{m}}$.
} 
who knew very well the birds breeding on the rookery, told me, as a great curiosity, that sometimes a pair of black-birds (uria troile) were breeding on the rocks, which were reddish-brown all over; they were described to me as being as large as the young alca torda, but of the habits of uria Brïnnichii. This was rather remarkable. I did not pay much attention to it, however, before last fall, when, in the collection of Mr. Secretary Benicken, in Sleswick, I was struck at the sight of an uria which he had received from Greenland, and which agreed closely with those described above. It was uniform reddish-brown all over the body, with darker bill and feet, and of the size of a young alca torda. The bill, differing from that of all known Guillemots, had shape and size intermediate between that of uria Brïnnichii and uria grylle. It sometimes happens that albinistic varieties are found among the northern birds; thus I know of white varieties of uria grylle, uria alle carbo graculus, anas histrionica, but I never happened to observe the pure white color varying into the darker, as would here be the case, as the uria presently named can by no means be regarded as a variety of any other species than uria Briinnichii, which always has the breast and belly white. The bill and the whole body, however, are too small for an old uria Brïnnichii; but this uniformily colored uria must be old, as it is said to have bred on the rookery at Drangöe. It may [p. 982] also be remarked that Fabricius (in the faun. Groenl. p. 81, No. 3) mentions an uria dorso rubro, for the rest similar to uria Brïnnichii, and Ström, in his description of Sundmör $(I, p .219)$, speaks of an alca pectore ribro."

This is the original description of Uria unicolor. It will be seen that $U$. motzfeldi has the priority over Faber's name by one month, consequently the one to be adopted if the bird should turn out to be distinct.

The next time the bird is mentioned is in the same journal for 1826 , where Brehm (on p. 988) speaks of "Uria unicolor Benicken" as being "blackish-brown," but too little known to him to be assigned its precise position.

Brehm, therefore, is the originator of the "Uria unicolor BENICKEN," a quotation afterwards to be found in most cases when the bird has been mentioned.

We have seen that Faber in 1824, in describing Uria unicolor, regarded it as mostly allied to $U$. brïnnichii. He seems afterwards to have changed his opinion, however, for in the continuation of his elaborate monograph (Beyträge zur arctischen Zoologie, VIII, Isis, 1827, p. 639) he speaks only of "Variat. extraord. aris tota alba vel tota nigra," under the heading of Uria grylle. U. unicolor is not mentioned at all, but it is almost certain that this "variatio extraordinaria" "tota nigra" of grylle is the same thing.

Brehm, in his "Handbuch der Naturgeschichte aller Vögel Deutschlands" (1831, p. 985), does not add anything to what he said in the Isis for 1826 . 
The next time we find any allusion to this totally black "Tyste" is by Bonaparte, who, in his "Catalogo Metodico degli Uccelli Europei" (Bo logna, 1842 , p. 82), introduces as European No. 532, Grylle carbo. BRANDT the habitat of which is given as "Bor. Eur. or. As." It seems hardly doubtful that it is Faber's Icelandic bird which is meant.

Two years later Herman Schlegel mentions our bird (Rerue Critique des Oiseaux d'Europe, 1844, p. 106) in the following words:

"Uria unicolor Faber (Isis, 1824, p. 981), from Iceland, seems to me to be an accidental variety of Uria grylle. We have received a simila specimen from Greenland."

In the same year Naumann (Naturgeschichte der Vögel Deutschlands XII, 1844, p. 485) mentions only in passing "Uria unicolor (Benicken)" as an Arctic species, uniformly dark reddish brown all orer the body but like Faber at first, and Brehm afterwards, he refers it to the re stricted genus Uria, and not to Cepphus (= Grylle).

Subsequent writers have mostly referred Faber's bird as an individua variety either to grylle, troile, or brïnnichii. As their conclusions ar based solely on what has been quoted above, no further remarks upor them is necessary. It may only be added that Bonaparte, in 1856 in his Catalogue Parzudaki, enumerates $U$. unicolor as doubtfully Eu ropean.

Nothing more became known about this puzzling bird until Prof. A Newton, in his well-known "Notes on the Birds of Spitzbergen" (Ibis 1865, p. 518), mentioned another specimen, said to have come from Ice land. He says :

"In Cepphus carbo again, and in what is perhaps another species, the white spot [on the wing] entirely disappears," and in a foot-note he adds "I refer to a specimen in the British Museum, marked 'Tria carbo', bu which wants the white eye-patch of that species, and is entirely blacl all over. This specimen was bought of Mr. Argent, and said to com from Iceland, which is just possible, since Faber speaks of an entirely black variety of Uria grylle from that locality (Isis, 1827, p. 639). What and when described, is Uria unicolor, Benicken"? I cannot trace i back beyond a note of Brehm's (Isis, 1826, p. 988). Under the nam of Uria motzfeldi Benicken described a Guillemot entirely black, bu differing from $U$.grylle by being much larger (Isis, 1824, pp. 888, 889) The British Museum bird is much the same size as that species."

After this we have to record Schlegel's account of a specimen in Lei den, mentioned in his "Muséum d'Histoire Naturelle des Pays-Bas" No. 33, Livr. 9, Urinatores, Avril 1867, p. 20, where, as No. 27, unde Alca grylle, is enumerated a specimen, of which he says: "Specimen with the plumage of an absolutely uniform smoky black, from Green land, obtained in 1859 ; one of the types of Faber's Uria unicolor."

Schlegel's last account is very puzzling, as Faber had only one type that being Benicken's specimen from Greenland, the very same on upon which the latter had already based his $U$. motzfeldi. On the othe 
hand, is this specimen not the one mentioned by him as received in Leiden as early as 1844, and is not 1859 only a misprint for 1839 ? Or had Schlegel actually two similar specimens before him?

I cannot now lay hands on Holböll's papers, but I find in Professor Newton's "Notes on Birds which have been found in Greenland" (Are. tic Manual, p. 109, 1875), that "Holböll says he has seen in Greenland an entirely black example."

So far as I know, none of the later expeditions into the Arctic mentions having met with these totally black birds except Mr. L. Kumlien, the naturalist of the "Howgate Polar Expedition, 1877-78," on the schooner "Florence," who saw three specimens, of which one was securec?. He writes as foliows (Contributions to the Natural History of Aretie America. = Bull. U. S. National Museum, No. 15, p. 105): "I have seen three entirely black specimens, which I considered to be $U$.carbo. One was procured in Cumberland, but was lost, with many others, after we arrived in the United States. I have examined specimens of carbo since, in the Smithsonian collection, and my bird was nothing but a melanistic specimen of $U$.grylle." It may be remarked, however, that in the Smithsonian Institution (or more correctly the National Museum) is, and has been, only a head of C. carbo, and that Mr. Kumlien's conclusion that his bird was only a melanistic stage of grylle was not based upon actual comparison. The finer differences in structure and color may easily hare escaped his attention or his memory.

When looking over the references collected together above, one can hardly escape the impression, that they all refer to a really valid species and no individnal variation, no melanism.

To begin with, there are known to exist, in collections, two specimens at least-one in Leiden, the other in the British Museum-which, judging from the descriptions, must be alike, and, on the authority of Schlegel and Newton, most nearly related to $C$. grylle (or, perhaps, rather $C$. carbo).

Assuming now that Schlegel's specimen, described by him as "d'un noir enfume absolument uniforme," is the very same as that upon which U. motzfeldi was based, we will be justified in concluding that Faber's designation of its color, "reddish brown," was incorrect and probably only taken down from memory. Furthermore, it can hardly fail that the bill differs as much from that of the grylle as does the color of the plumage. Benicken's and Faber's descriptions are too distinct to admit of doubt on this point. Schlegel, it is true, does not mention any difference in the shape of the bill, but including, as he did, $C$. columba under grylle, it is evident that he allowed a much greater individual variation than is permissible. Nor does Newton say anything about the bill of the British Museum specimen, but the fact that it was labeled "Uria carbo" might perhaps indicate that the bill is shaped somewhat as in the latter species.

As to the size, Professor Newton remarks that the British Musenm 
specimen is of about the same size as grylle. Benicken and Faber expressly say that their type was larger, but as no measurements of wing and tail are given, we have no means of rerifying their statements, which may possibly be due to overstuffing of the specimen. The only measurements of which we can make use are those of the bill and tarsus as giren by Benicken.

To facilitate the comparison, the measurements are combined into a synoptical table, including Benicken's measurements as giren above, the arerage dimensions of 7 old $C$. grylle in the black summer-plumage, and the dimensions of the bill of a head of $C$. carbo, from Japan (U. S. Nat. Mus., No. 21270).

Comparative table of measurements.

\begin{tabular}{|c|c|c|c|c|c|c|}
\hline Species. & Specimens. & 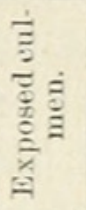 & 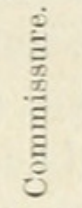 & \multicolumn{2}{|c|}{$\begin{array}{l}\text { Bill from tip } \\
\text { to fore bor. } \\
\text { der of- }\end{array}$} & 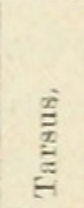 \\
\hline
\end{tabular}

* Benicken sars: "Length of bill from the nostrils" (Länge des Schnabels von den Jasenlöch.), but as $24^{\mathrm{mm}}$ is disproportionate to the other dimensions of the bill, as giren by him, I suppose that he measured from the anterior border of the nasal groove; or " 1 inch " mas perbaps be a misprint.

$\dagger v$. Schrenck's measurements of the tarsus of three individuals of this species amounts to 35 mm (Reis. Amurl. I, p. $\left.497: 1^{\prime \prime} \cdot 4 \frac{1}{2}^{\prime \prime \prime}\right)$.

It seems apparent from the table, that Benicken's specimen cannot have been merely an individual color variety of $C$.grylle, as the differences in the size of the bill and tarsus are too great and far beyond the limits of individual variation of the latter species. On the other hand, the agreement with $C$. carbo in regard to size is very striking, and if the British Museum specimen agrees with Benicken's type in this point, its reference to $C$ : carbo is easily explained. It is true that Professor Newton does not mention this, but it seems as if he had not the specimen before him when writing his Notes on the Birds of Spitzbergen, or he would hardly have failed to give a more explicit description of the bird in question.

To regard Benicken's bird as a melanistic stage is hardly defensible in the view of his description of the color: "entire plumage sooty black, on the abdomen shading somewhat into grayish." We have already remarked that Faber's description of the color as "reddish brown" is not to be relied upon; but it can hardly fail that the plumage had a brownish hue, or this careful observer would not have made so egregions a mistake. It also argues greatly against the probability of melanism as the true explanation that so many individuals have been observed: two are in museums, three were seen-one of which was collected-by Kumlien, one observed by Holböll, not to speak of those mentioned by Faber as breeding at Drangö. It is rery suggestive that all these are reported. from Green'and and Iceland, and none from Europe or Spitzbergen. 
I am strongly inclined to the belief that there are two black-winged Guillemots, one $O$. carbo, from the western part of the North Pacific Ocean, the other from the western part of the North Atlantic, O. motz. feldi, the difference of which are that the former has a white patch round the eyes, while in the latter the head seems to be uniformly dark colored without any distinct pattern.

It has been suggested that these whole-colored Black Guillemots observed and obtained in the Northwest Atlantic really might have been true O. carbo, stragglers from the Pacific, and instances of North Pacific birds accidentally caught in the Atlantic have been quoted in this connection, for instance Lunda cirrhata in Greenland and Cyclorhynchus psittaculus in Sweden. It may be remarked that these two species are of general distribution in the North Pacific, while $O$. carbo is confined to the Okotsk and Japanese seas. It speaks furthermore against this theory, that so many examples have been observed, and that we have, indirectly at least, the testimonies of Schlegel and Newton, that the two specimens known are not referable to $C$. carbo.

The question whether we have to deal with a distinct species or not is an exceedingly important one, and anybody having the opportunity of examining the specimens in Leiden and London would earn the thanks of his fellow-ornithologists by publishing a detailed deseription and compasison. It is hoped that if anybody does so he will give the particulars of his investigation so explicitly that others may be enabled to form an independent opinion upon them, and that we will not have to content ourselves with the results which he thinks he has obtained, as is the usual way of many ornithologists.

In the meantime, the attention of such ornithologists should be directed to the same question, who have the opportunity of investigating or promoting investigation of the North Atlantic waters. Everything seems to indicate that such a bird may be found somewhere in the neighborhood of Greenland, and may be considered as well entitled to a place in the North American faunal lists as many other species. It is now for American ornithologists to prove that it really exists and that it really belongs to our avi-fauna.

\section{II.-ON THE WHITE-WINGED SPECIES OF THE GENuS CeppHUS.}

Cepphus mandtii was first obtained and described from the sea between Spitzbergen and Greenland, and was subsequently found in both of these islands, from which, also, the original $0 . g r y l l e$ was reported simultaneously as an inhabitant.

In Europe Mandt's Tyste has been generally recognized, by some as a geographical race only, Schlegel, Sundevall, \&c., designated by a trinominal appellation, while other authors, and especially Prof. A. Newton, maintained its right to rank as a distinct species.

North American ornithologists, however, up to the present date, have ignored the form altogether, although it has been positively stated to 
breed in Greenland. Cassin in Baird's "Birds of North America " (1858) placed it with query as a synonym of $C$. columba, and Dr. Coues, most unfortunately, followed him (partly) when publishing his "Monograph of the Alcidæ" (Pr. Philada. Acad. 1868), in spite of Professor Newton's excellent indication of the species three years previous (Ibis, 1865). Since that time American Ornithologists have been silent about it.

This seems ratter singular, but is now easily explained, as, by going over the ample material, I find that in most cases the American Ornithologists had only had the true $C$. mandtii before them, and that they have hardly been acquainted with the true $C$. grylle, which it seems is rather of restricted distribution in North America. They have mistaken the common American bird for C.grylle for want of sufficient material for comparison, being under the impression that the latter should be the common form, while mandtii was generally regarded as an inhabitant of the most icy and Arctic regions. Material which has accumulated only very recently has led me to this conclusion, and also convinced me, that mandtii is a perfectly good species, rather easy to distinguish and describe. I am thus able to fully corroborate Professor Newtown's views, alluded to above. As even the history of $C$. columba has been involved in some doubts-Schlegel placed it with grylle as a synonym-it may be expedient to treat of this species also in the present connection.

Before beginning a detailed comparison of the three species of Tyste, with white wing-patches, a few general remarks may not be out of place.

A certain distinction between the young and the adults of these three species is the presence or absence of dusky at the tip of the feathers forming the white wing-patch or speculum. It is not fully es. tablished whether these dusky ends disappear as early as at the first moult of the wing feathers following the breeding season next after that in which the bird was born, or, in other words, when one year old, or whether they first are lost in the second year, so that the bird would not breed before nearly three years of age; for I do not think that the Tyste breeds in the plumage with the spotted speculum, at least I never saw one. To me it seems most probable that the wing-coverts become white as early as the first moult, that is, when fully one year old, and that they breed in the second season following that in which they were born.

In the history of these species the immature birds with the dusky spotted speculum have caused great confusion. Not that the young of the three species are indlistinguishable in this plumage, but as the characters are not so pronounced in the immature as in the adult-as usually among birds-their taking into account when comparing the the species will necessarily obscure the result. If Dr. Finsch had not mixed old and young ones indiscriminately together in his detailed account of the specific difference of grylle and mandtii, he most probably would have reached a result coutrary to that he arrived at (2te Deutsche 


\section{PROCEEDINGS OF UNITED STATES NATIONAL MUSEUM.}

Nordpol-Fahrt, II, p. 221 seqv). It is therefore absolutely necessary that the comparison should be made between fully mature birds, in the black plumage, and without dusky tips to the wing-coverts. If an investiga. tion based upon such material shows trenchant and constant characters, then we have all that is needed to establish good and undoubted species.

As all winter specimens in the light and mottled plumage and all immature birds with mottled wing-speculum are to be rejected, a large material, of course, is needed. I have had unusual facilities in that respect, and I doubt that any ornithologist has ever had 78 good specimens, besides downy young of these three forms, as I have now before me. In this vast series are birds from almost all quarters where these species occur: Atlantic and Baltic coasts of Scandinavia, Spitzbergen, Orkneys, Iceland, Greenland, Cumberlaud Sound, Hudson's Bay, northeastern coast of North America, Point Barrow, Herald Island, northeastern corner of Asia, Alaska, Kamtschatka, Aleutian Islands, and west coast of North America as far down as San Francisco and San Miguel in California. Of these 78 specimens some 30 are adults in the plumage indicated above. All of these have been examined, but only the measurewients of 25 have been given below, as the mounted specimens have not been measurer in order to secure perfect uniformity of the measurements. I trust that all necessary precautions to obtain conclusive results have thus been taken. In the following, consequently, is only meant specimens in totally black (not even partially mottled) plumage with no dusky tips on the white upper wing-coverts, unless otherwise stated.

There is one character which in all ages and plumages is sufficient at the first glance to distinguish $C$. columba from the two other species, viz, the color of the under wing-coverts, these being always more or less brownish gray or smoky in C. columba and pure white in C. grylle and mandtii. This character is "unfailing," and not only distinguishes the adult birds, for I have young before me still partially in the down, in which it is as fully diagnostic as in adults in full breeding plumage or in the light winter garb, and in all the 78 birds no one exception or intergradation. To this mark may be added several others, as will be seen from the tables of dimensions, as given below; columba is altogether the larger bird, the toes besides being disproportionately longer than in the other species, the bill stouter, ete. As a rule C. columba has 14 tail-feathers, while the other two have only 12, a very remarkable feature, though one which is not always to be relied upon, as individuals of grylle* occasionally are found with 14 and of columba with 12 rectrices. The unconditional reliance upon this character caused v. Heuglin to identify a bird with 14 tail-feathers from Spitsbergen as $C$. columba, a mistake he never would have made had he looked at the color of the under wing coverts. A further difference is

* Brehm seems to have had specimen of mandtii with 14 rectrices. Cf. Naumannia 1855 , p. 300. 
found in the black cross-bar of the wing-speculum, a peculiarity to be discussed more in detail further on, when speaking of C. grylle.

Finally a character should be mentioned which may seem trifling, but nevertheless is very constant. In grylle and mandtii the black has a faint but decided greenish gloss, which in columba is substituted by a less glossy slate-colored wash on the back, with indication of purplish on the abdomen. In old museum specimens of columba the tinge is rather brownish, but the absence of green is always well marked.

No one who ever had the opportunity of comparing authentic specimens of $C$. columba can doubt its absolute validity as a species.

It has already been pointed out by Prof. A. Newton, aud I am in the position of being able to undorse his statement most emphatically, that "there exists an unfailing means of differentiating Cepphus mandtii from C. grylle. This lies in the feathers which form the conspicuous wingspot. In the more northern form from Greenland and Spitsbergen they are pure white at the base, even in immature birds, while in the true C. grylle, from our own islands, Iceland and Norway, with its stouter bill, these feathers are always black at the base, forming an entirely, or almost entirely, concealed band across the wing-spot." It may be added, however, in order to avoid mistakes, that not all "the feathers which form the wing-spot" are meant, but onl the large coverts of the secondaries, the so-called "greater upper wing-coverts."

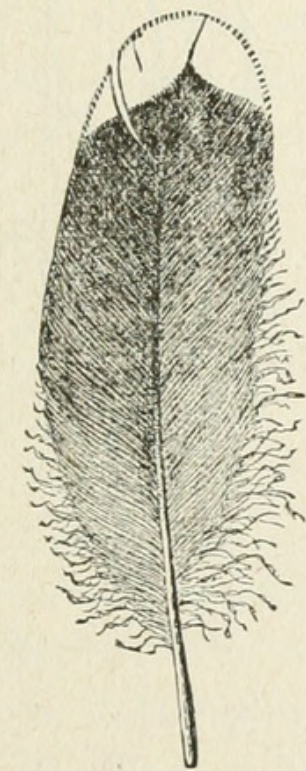

Fig. 1. Cepphus columba, ad.

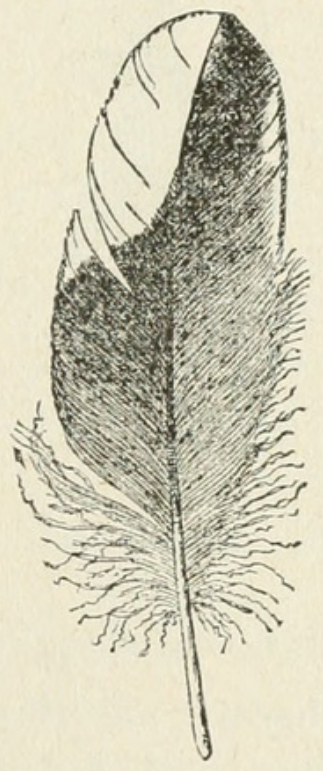

Fig. 2. Cepphus grylle, ad.

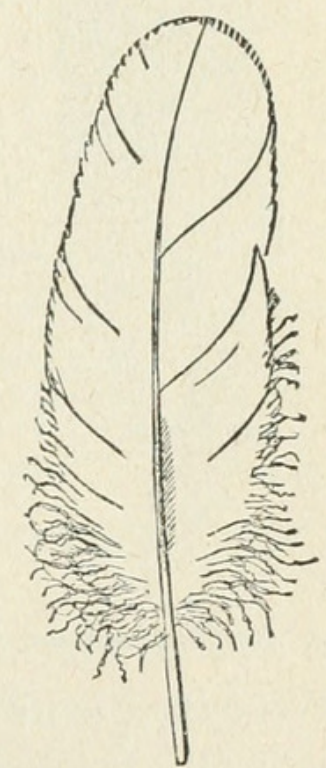

Fig. 3. Cepphus mandtii, ad.

The large series before me is easily divided into two groups. In the one the greater wing-coverts are white to the very base, with or without an indistinct dusky line along the basal half of the shaft (fig. 3); all birds thus colored have a slenderer bill. In the other group the greater wing-coverts are black or blackish for about their basal half or more, with a sharp outline towards the white of the terminal half (fig. 2); all birds thus marked have the bill stout and stroug. The former belong to $C$. mandtii proper, the latter to the true $C$.grylle. The black bases of the greater wing-coverts in grylle form a continuous black cross-bar 
over the speculum; just after the moult, when the feathers are entirely fresh, the ends of the middle coverts will usually conceal the black baralthough it mostly shines through-but later in the season the overlying tips are worn away and the cross-bar becomes visible; at all events it can be seen by gently pushing the middle coverts a little aside, as there is no need of lifting them up in order to detect the black bases of the underlying feathers. On the other hand, no abrasion or removing of the middle coverts will ever produce anything like the dark crossbar in $C$. mandtii.* The stoutness and slenderness of the bill as coincident with the presence or absence of the cross-bar is very marked.

There is no difficulty, then, in telling the old birds apart, as they are distinguishable at a mere superficial glance. Adult birds in winter plumage have also the speculum pure white, that is to say, without blackish or dusky spot and mottlings at the tip of the feathers. These are only moulted once a year, and are consequently the same as those of the black summer plumage; the character is therefore just as well marked in the winter garb. In the young birds a little more caution and closer inspection are needed, and, in fact, there is usually more dark color at the base in these than in the adults (Figs. 5, 6), but in all speci-

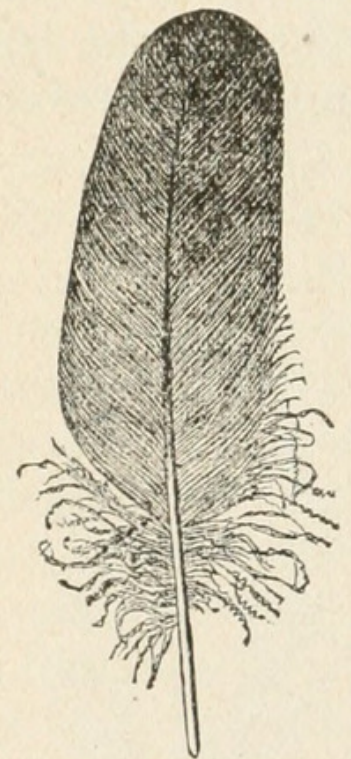

Fig.4. Cepphus columba, jun.

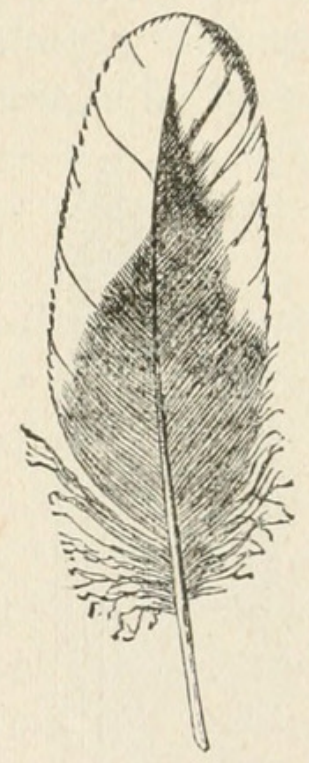

Fig. 5. Cepphus grylle, jun. Fig. 6. Cepphus mandtii, jun.

mens of the large number before me the characteristics of the two forms are well expressed, not a single reference of a specimen is questionable, and I doubt whether specimens really are found which are not easily attributed to the one or the other species.

The young mandtii has the tips of the primary coverts and of the secondaries more or less broadly edged with white, which is said never

* It is only just to mention that the value of this character was not first pointed out by Professor Newton, as he and others have thought, for Brehm, in his original description of $U$. glacialis (1824), mentions it in very explicit words. He says (Lehrb. Eur. Vög., p. 925): "The long upper wing-coverts are white to their very base, and therefore no black cross-bar is produced on the wing of the old bird (one may push the feathers aside ever so much) like that in the two foregoing species" [Uria grylle and Uria arctica BREHM]. 
to be the case in grylle, a feature of which I am unable to speak with absolute certainty, as I have too few young grylle at hand.

There is another character which holds good, provided only the corresponding ages be compared, viz, the extent of the white on the inner web of the primaries. This color ascends from the base like a "wedge" and in the old grylle does not reach further, when looked upon from the lower surface of the wing, than to about the end of the longest underwing-coverts, while in mandtii it goes $15-25^{\mathrm{mm}}$ beyond these. In the young the white wedge is larger, and consequently reaches beyond the coverts also in grylle, but the corresponding age of mandtii will be found to have them still larger.

In general coloration the two species do not differ materially, except in the winter plumage, which is considerably whiter in mandtii than in true grylle. As full winter plumages of adults of the latter is the weak point of my series I refrain from a detailed comparison, but I have, at home in Norway, handled enough specimens of grylle to state that a true grylle is never found so white at any season as mandtii in adult and full winter garb.

It will be seen that $C$. mandtii is distinguished at once from its two nearest allies by a white wing-patch unbroken by any black cross-bar, concealed or not. The latter is a character common to both grylle and columba, which, however, are readily distinguished by the characters given above. But, as indicated, the pattern of the speculum also differs materially in the two species. In grylle (Figs. 2,5) the white tips of the greater wing-coverts are of about the same size in all the feathers, the black cross-bar consequently being of almost equal breadth in the whole extent. In columba (Figs. 1, 4) on the other hand, the white tips decrease towards the edge of the wing, the black bases correspondingly increasing, so that the bar becomes much broader anteriorly, almost assuming the shape of a triangular black wedge.* This is not the only difference, however, for in columba almost all the coverts have got black bases, which often are so pronounced as to form a second visible crossband on the speculum.

To complete the comparison four tables of measurements are here added. The first shows the superior size of $C$. columba, and the disproportionate length of the toes; second and third prove the slenderness of the bill of mandtii as compared with grylle, and in the fourth the averages are put together to facilitate the comparison.

\footnotetext{
* In most young specimens the first ones of the greater coverts are entirely black.
} 
I.-Table of dimensions of Cexpues columBa (Pall.).

[old birds in black surnmer plamage only.

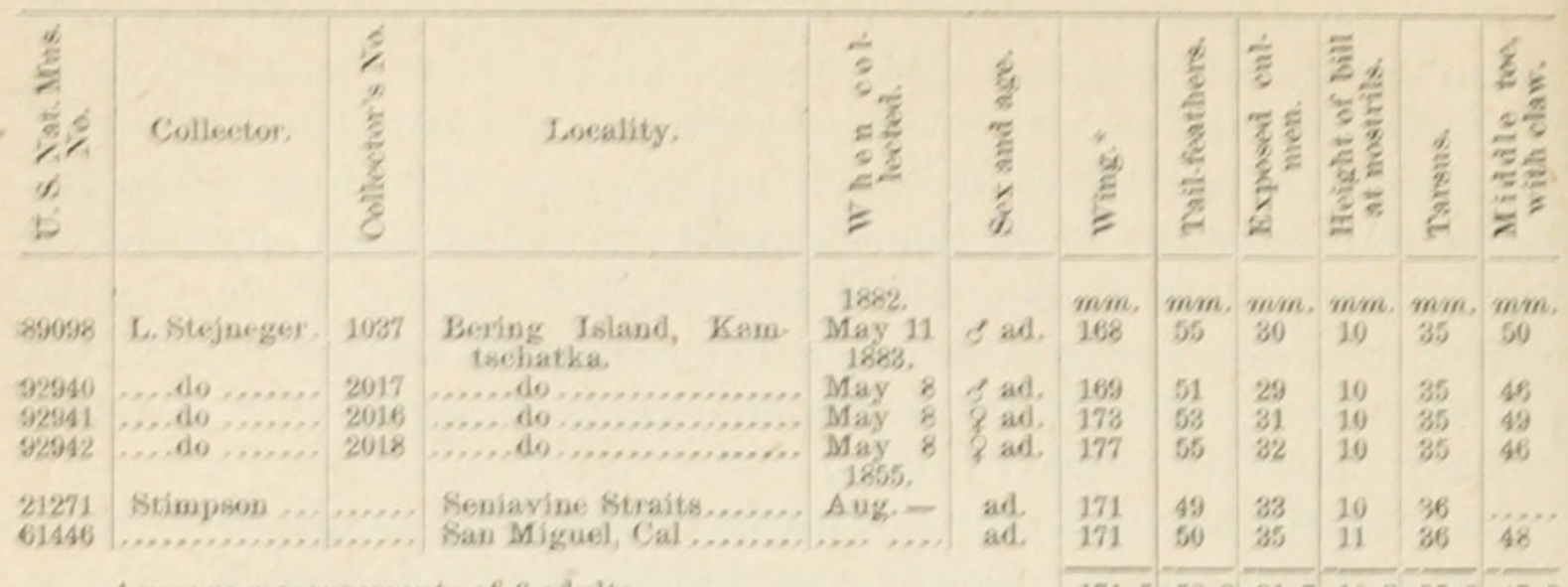

A yerage measurements of 6 adults

\begin{tabular}{l|llllll}
171.5 & 52.2 & 31.7 & 10,2 & 35,3 & 47.8
\end{tabular}

The wing, in this and the following tables, is measured with dividers, the curve not being flattened.

II.-Table of dimensions of CEPPsus GRYLLE (Lin.).

[Old birds in black summer p'umage only.]

\begin{tabular}{|c|c|c|c|c|c|c|c|c|c|c|c|}
\hline 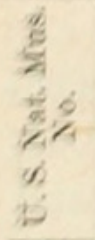 & Colleetor. & $\frac{\frac{6}{2}}{\frac{1}{5}}$ & Locality, & $\begin{array}{l}\frac{1}{8} \\
0 \pi \\
\frac{\pi}{8} \\
2 \frac{8}{2} \\
\frac{2}{2}\end{array}$ & $\frac{\sqrt[3]{3}}{\frac{3}{8}}$ & 㞔 & $\frac{\frac{d}{2}}{\frac{2}{z}}$ & 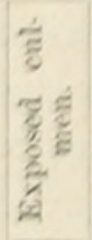 & 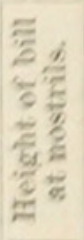 & $\frac{d}{E}$ & 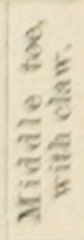 \\
\hline $\begin{array}{l}62381 \\
24293 \\
95256\end{array}$ & Stojneger & $\begin{array}{c}1 \\
370\end{array}$ & $\begin{array}{l}\text { Eastport, Me .......... } \\
\text { Orkney lslands ......... } \\
\text { Stavanger, Norway .... }\end{array}$ & \multirow{3}{*}{$\begin{array}{l}\text { July } 1 \\
1879 \\
1864 . \\
\text { May } 3 \\
\text { 1884. } \\
\text { Apr, 20 } \\
\text { Spring }\end{array}$} & \multirow{3}{*}{$\begin{array}{l}\text { ad. } \\
\text { ad. } \\
\text { ad. } \\
8 \text { ad. } \\
\text { f ad. } \\
\text { g ad. } \\
\text { ad. }\end{array}$} & $\begin{array}{l}m m \\
166 \\
158 \\
160\end{array}$ & $\begin{array}{l}m m \\
51 \\
50 \\
51\end{array}$ & $\begin{array}{l}\operatorname{mm} \\
29 \\
31 \\
32\end{array}$ & $\begin{array}{c}m m . \\
9 \\
10 \\
9\end{array}$ & $\begin{array}{l}m m, \\
32 \\
33 \\
32\end{array}$ & $\begin{array}{l}m m, \\
43\end{array}$ \\
\hline $\begin{array}{l}34122 \\
98074\end{array}$ & $\begin{array}{l}\text { Mus, Stoekh. } \\
\text { Mus. Bergen. }\end{array}$ & & $\begin{array}{l}\text { Stoekholm, Sweden .... } \\
\text { Bergen, Norway........ }\end{array}$ & & & $\begin{array}{l}170 \\
150\end{array}$ & $\begin{array}{l}58 \\
48\end{array}$ & $\begin{array}{l}33 \\
29\end{array}$ & $\begin{array}{l}10 \\
10\end{array}$ & $\begin{array}{l}34 \\
30\end{array}$ & $\begin{array}{l}43 \\
41\end{array}$ \\
\hline \multirow[t]{2}{*}{$\begin{array}{r}98075 \\
1965\end{array}$} & Audubon & & "3...... do, & & & $\begin{array}{l}154 \\
162\end{array}$ & $\begin{array}{l}52 \\
58\end{array}$ & $\begin{array}{l}32 \\
31\end{array}$ & $\begin{array}{r}10 \\
9\end{array}$ & $\begin{array}{l}31 \\
32\end{array}$ & 43 \\
\hline & \multicolumn{5}{|c|}{ 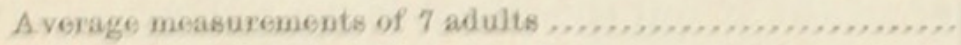 } & 159. 3 & 51.8 & 31,0 & 9.6 & 32.0 & 42.5 \\
\hline
\end{tabular}

II.-Table of dimensions of CexpuUs MaNdotir (Lielit.).

[Old birds in black summer plumage only.]

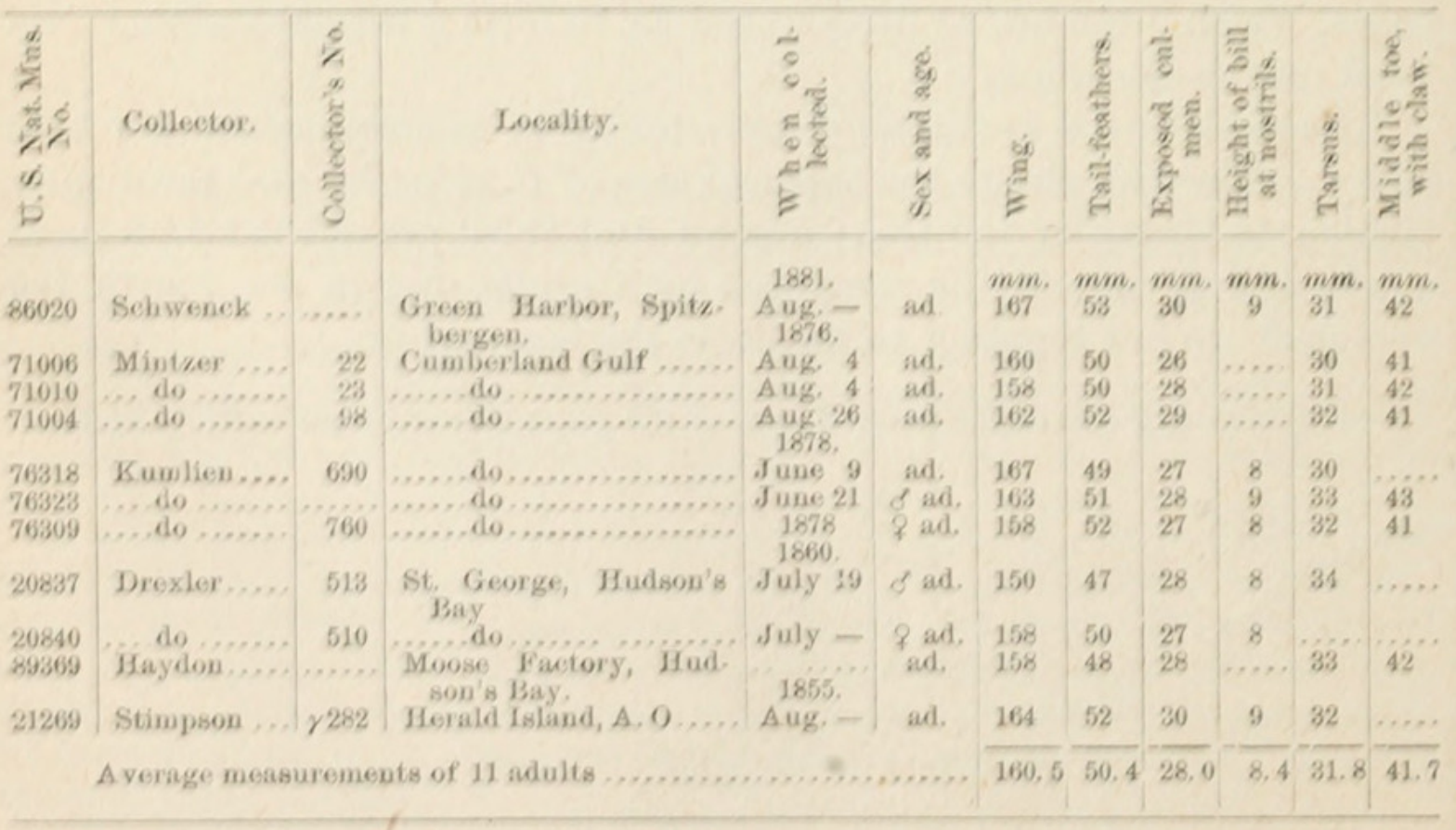


IV.-Comparative table of dimensions.

\begin{tabular}{|c|c|c|c|c|c|c|c|}
\hline Species. & Specimens. & $\stackrel{\dot{\varepsilon i 0}}{\Xi}$ & & 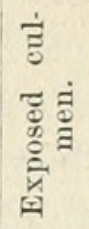 & 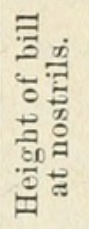 & 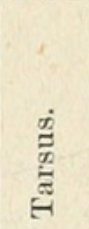 & 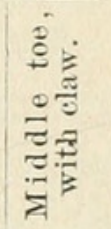 \\
\hline $\begin{array}{l}\text { C. columba.. } \\
\text { C. grylle } \\
\text { C. mandti... }\end{array}$ & $\begin{array}{l}\text { A verage measurements of } 6 \text { adults...... } \\
\text { A verage measurements of } 7 \text { adults .... } \\
\Lambda \text { verage measurements of } 11 \text { adults.... }\end{array}$ & $\begin{array}{l}\operatorname{mm} . \\
171.5 \\
159.3 \\
160.5\end{array}$ & $\begin{array}{l}\operatorname{mim} . \\
52.2 \\
51.8 \\
50.4\end{array}$ & $\begin{array}{l}\operatorname{mim} . \\
\text { 31. } \\
31.0 \\
28.0\end{array}$ & $\begin{array}{r}m m . \\
10.2 \\
9.6 \\
8.4\end{array}$ & $\begin{array}{l}m m . \\
35.3 \\
32.0 \\
31.8\end{array}$ & $\begin{aligned} \operatorname{mm} . \\
47.8 \\
42.5 \\
41.7\end{aligned}$ \\
\hline
\end{tabular}

By the discovery that the American species is mandtii, our ideas as to the

\section{GEOGRAPHICAL DISTRIBUTION}

of the three species must be considerably modified. Large areas must be detracted from $C$.grylle, and the range of mandtii extended correspondingly.

\section{Cepphus mandtii}

is circumpolar in its distribution. It is the form known to inhabit Spitzbergen (Malmgr. Newt. Heugl., U. S. Nat. Mus.) and Novaja Semlja (Henglin); it has been found breeding in Greenland (Faber, Finsch, U. S. Nat. Mus.), and also - and, as it seems, exclusivelyon the opposite side of Davis Strait and Baffin's Bay (Kumlien, Feilden, U. S. Nat. Mus.). It is this species which breeds in abundance on Herald Island, north of Bering's Strait (U. S. Nat. Mus.), and there is not the slightest doubt that it is the same species which was found by Mr. E. W. Nelson on Wrangel Island. Nor is it reasonable to suppose that the Guillemot met with by the "Jeannette" party, breeding on Bennett Island, one of the New Siberian Islands, belonged to another species, and the "few Black Guillemots" found by the naturalists of the "Vega" expedition, on Preobraschenij Island, on the coast of the East Taimyr Peninsula, were in all probability the same. In the old world Mandt's Tyste does not seem to breed outside of the Arctic Seas, while on the American side of the Atlan tic its breeding range extends considerably further southwards, being, as it seems, from the proportion of the specimen $\mathrm{s}$ in the National Museum, the most numerous form in the northeastern coast of North America, although no specimens in breeding plumage are from any locality south of Labrador. The National Museum possesses adult birds in breeding plumage from St. George, Hudson's Bay, collected by Mr. Drexler, and also half-fledged young from the same locality.

During winter many individuals remain at the place of their birth, provided open water be found in the neighborhood, while many go further south The National Museum has winter specimens from St. Michael's and Point Barrow, in Alaska, from Eastern North America, Cumberlaud Sound, and Iceland. In all probability, a portion of the Spitzbergen birds winter on the coast of Northern Norway, and those 
from Novaja Semlja may come down to the Baltic, but nothing definitely is known.

Immature specimens in black plumage, but with mottled speculum, are often found south of the breeding range of the species during summer. Thus, I have seen specimens of that kind collected by Mr. Nelson at Stewart Island, near St. Michael's, Alaska, in the month of June. There is no reliable account, however, of the bird having bred south of Berings Strait.

\section{Cepphus grylle}

breeds on the coast of northern and northwestern Europe. It occurs from the White Sea all around the shores of the Scandinavian Peninsula and Finland, and is still found breeding on several of the Danish Islands, including Bornholm, in the Baltic, one of its most southern breeding places in Europe, being less numerous, however, in the lower latitudes than higher north. On the British Islands and Ireland it is confined to the northern parts, and is found on the Hebrides, on St. Kilda, the Shetland Islands, and the Orkneys. Common on the Fær Islands and all round Iceland; "numerous nowhere, but common everywhere," as Faber says. The Tyste is a partial resident in the countries where it breeds, but many retire to somewhat more southerly latitudes during the coldest season. At that time they are found common at the German coasts of the Baltic and the North Sea, the southern parts of Great Britain, and more rarely along the coasts of the Netherlands and Northern France.

In the Western hemisphere its distribution seems to be much more limited. It is known to breed in Greenland (Finsch, U. S. Nat. Mus.), and probably also on several localities along our northeastern coast; but as the authors of local faunas have not distinguished between mandtii and the present species, the true grylle, and as the Museum possesses only few authentic American specimens in breeding plumage, nothing can be said with certainty about its breeding range on our continent. An old bird in full summer plumage without black mottlings on the speculum is in the collection, from Eastport, Me., July 1, and this is the only certain locality at present known to me. But I think it is safe to assume that this is the more southern form, and that it is not found north of Newfoundland, the species which Bryant found breeding in the Saint Lawrence Bay probably being the one in question. During winter it cones further south, and a specimen from that season is in the Museum, having been shot at Philadelphia.

It is most important that the ornithologists along the coast from New Jersey to Labrador should be on the lookout for these birds in order to have determined, as soon as possible, the exact range of so interesting a breeding bird of the United States.

The species does not at all occur in the Pacific Ocean, and all references from there and the adjacent portions of the Arctic Ocean belong to columba and mandtii. 


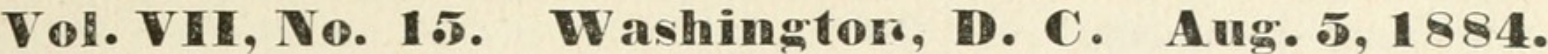

\section{Uria columba}

is confined to the Pacific Ocean. Its geographical distribution is very interesting, as it breeds as far south as Southern California, consequently much farther south than the two Atlantic species wander even in winter.

From the coast of California this species extends northward all along the western coast of North America way up into Alaska, and all over the Aleutian Islands. There are no reliable instances known, however, of its having been obtained north of Berings Strait, although the National Museum possesses specimens from Plover Bay and from Seniavine Strait at the Tschutski Peninsula, where it is said to be common (Cassin, Pr. Ac. Phil., 1862, p. 323), but these localities are within Berings Sea.* On the Asiatic side it is well known from the shores of Berings Sea, and I found it myself quite common on the eastern coast of Kamtschatka and on the Commander Islands, from where I have brought home numerous specimens. It is not known from the Okhotsk Sea, although specimens have been taken at the Kurile Islands, but whether breeding there I cannot say, as it is possible that those obtained there were only immature birds. It winters about these islands and about Yezo, the northern island of Japan proper. It will be seen that the species is much more northerly on the Asiatic than on the American side of the Pacific. It seems to be replaced further south on the Asiatic coast by C. carbo.

\section{III.-Has Cepphus CARBo EVER BEEN OBTAINED Within THE} FAUNAL LIMITS OF NORTH AMERICA?

The original describer of the species, Pallas, in his Zoographia RossoAsiatica (II, p. 350), gives the habitat of Cepphus carbo in the following words: "Inhabits only the Eastern Ocean, about the Aleutian Islands,

* This is the case, notwithstanding Mr. E. W. Nelson's statement to the contrary in his "Birds of Bering Sea and the Arctic Ocean," p. 117. Of Cria columba he says: "This is the most abundant of the small Guillem ots throughout the North, from the Aleutian Islands to those of Wrangel and Herald, where we found it breeding abuudantly during our visit there in the Corwin. We found it near Cape Serdze Kamen, where it was nesting, and also in great abundance upon Herald Island, where it was perhaps the most abundant bird present, far outnumbering the Murre..... None were observed on the western portion of the New Siberian Islands by Nordenskjöld [true, Nordenskjöld does not mention any Black Guillemot, but he saw the islands only from a long distance off ], but the Chukchees reported it to him as wintering at Tapkan, whenever open water was found during that season." Any one taking the trouble of comparing these notes with those under the heading of his Uria grylle (= mandtii) will soon see that they refer to the same species, which is made the more certain by the reference to Nordenskjöld, who expressly calls his birds grylle. Here is another case, where the same species has been placed under two different headings, while the remarks on the true columba seem to have been dropped altogether. It may be remarked that Mr. Nelson brought no specimens home from those Arctic localities.

Proc. Nat. Mus. 84-15 
especially in the caves around Unalaschka, wherefrom I have received numerous specimens."

So far as I know, this is the only detailed and definite record of this species inhabiting any locality within the limits of the North American fauna. In view of the experience of later explorers, however, the statement must be regarded as erroneous. It has not been found in Unalaschka, by v. Kittlitz, Dall, Turner, Nelson, nor in fact by any of the many expeditions which have stopped there. The museum of the Academy of Natural Sciences in St. Petereburg never received it from the Russian possessions in America (since Pallas's days, at least), nor is it found from there in the Leiden Museum, or any of the other European or American museums which have received collections from that region. The Russian collector, Wossnessenski, who paid special attention to the water-birds, who collected successfully for many years on the Kuriles, Kamtschatka, the Aleutian Islands, and the coast of northwestern America, and whose discoveries and collections have added so much to our knowledge of the Alcida of those regions, found this species "only on the Asiatic shores of the Pacific Ocean, $e . c$, on the shores of the Okhotsk Sea, and near the Kurile Islands" (Brandt, Mél., Biol., VII, 1869, p. 206).

As to Pallas's positive testimony, contrary to these negative evidences, it may remarked that there is no question of an observation made by Pallas himself; nor does he give the name of any trustworthy observer, as is his usual practice. It seems as if the statement has been based upon specimens said to have come from Unalaschka, in which case there has been a mistake made in the locality. Several similar mistakes are found in his Zoographia, among others Leucosticte arctoa, from the same locality as C. carbo, Actitis hypoleucos from Kodiak, Hamatopus niger, from the Kuriles [?], and there is no more reason for including C. carbo among North American birds than Actitis hypoleucos. It seems as if the localities of a whole collection received at St. Petersburg had become mixed up, probably one of Merck's, who collected in all these places.

As remarked above, Pallas's statement is the only detailed and definite record of the occurrence of the species within our continent. To my knowledge the only statement besides which is not based upon Pallas's account is to be found in the second edition of Dr. E. Cones's "Key to North American Birds" (1884), where, on p. 815, the habitat of C.carbo is given as "N. Pacifie, in higher latitudes ; British Columbia to Japan" (italics mine). A diligent search through the literature has not revealed to me the observation or record of specimen obtained upon which Dr. Coues's statement is founded. I may have overlooked the reference, however, and it is of the greatest importance that Dr. Coues should make public his authority. It may be remarked that the state'ment is not found in the first edition (1872), nor in the same author's "Monograph of the Alcidæ" (Proc. Acad. Philada., 1868). 
The true habitat of $C$. carbo seems to be a very restricted one, being confined to the shores of the Okhotsk Sea and adjacent waters. Specimens in the museum of the Philadelphia Academy are said to be from Kamtschatka, being in all probability from the western or Okhotsk shore. Kamtschatka has its Okhotsk and its Pacific shores, as America its Pacific and Atlantic shores, and the difference between the two shores are proportionally the same. I doubt very much that $C$. carbo occurs on the Pacific side of Kamtschatka otherwise than accidentally, and I regard the two pairs seen by me at Bering Island in the spring of 1883 likewise only as stragglers. C. carbo is known to breed on the Kurile Islands, at the Bays of Abrek and of Decastrie, and is also reported from Yezo, the northern island of Japan.

\section{IV.-Synopsis OF THE SPECIES OF THE GENUS CEPphus.}

$a^{1}$. A large white patch on the upper surface of the wing.

$b^{1}$. Under wing-coverts pure white.

$c^{1}$. Greater upper wing-coverts white to the base, only dusky along the basal part of the shafts, ${ }^{*}$ forming no concealed or visible band across the wing-patch.

\section{C. MANDTiI.}

$c^{2}$. Greater upper wing-coverts, black in their basal half or more ${ }^{*}$ forming a concealed or visible black band across the wing-patch.

2. C. GRYLle.

$b^{2}$. Under wing-coverts more or less brownish-gray, or smoky, never white.

\section{C. columba.}

$a^{2}$. No white on the upper surface of the wing.

$b^{1}$. A whitish patch round the eyes.

\section{C. CARBo.}

$b^{2}$. No whitish patch round the eyes.

\section{? 5. C. MOTZFELDi.}

1. Cepphus mandtii (Licht.) Newt.

1774.-Colymbus grylle Phipps, Voy. tow. N. Pole (p. 186.) (nec Lin.).-Uria g. Baer, Bull. Scientif. Ac. St. Petersb. iii, p. 352.-Cassin, in Baird B. N. Amer., p. 911 (1858).-Id., Pr. Philada. Acad., 1862, p. 323.-MalmGren, Öfv. Sv. Vet. Acad. Handl. 1863, p. 111.-Id., Jour. f. Orn. 1863, p. 382.-Finsch, $2^{\text {te }}$ Deutsche N. Polfahrt, p. 221 (1874).-Feilden, Ibis, 1877 , p. 40.-1b., P. Z. S., 1877, p. 31.-NORDQuist, in Nordenskj. Vega Exped., Am. ed., p. 436 (1881).-Nelson, Cruise Corwin, p. 117 (1883).Cepphus g. Newton, P. Z. S., 1864, p. 495.

1822.-Uria mandtii Lichtenst, in Mandt's Obs. Itin. Dissert. (p. 30).-Id., Doubl. Verz., p. 88 (1823).-FABer, Isis, 1824, p. 980.-Keys. \& Blas. Wirbelth. Eur., I, p. xeii. (1840).-Na mavn, Naturgesch. Vög. Deutschl., xii, p. 462 (1844).-Evans \& Sturge, Ibis, 1859, p. 221.-Heuglin, J. f. Orn., 1871, p. 102.-Cepphus m. Newton, Ibis, 1-65, p 517.-Id., ibid., 1869, p. 241.-Gillett, Ibis, 1870 , p. 307.-HevGlin, J. f. Oru., 1871, p. 100.-Id., ibid. 1872, p. 124.-Id., Ibis, 187\%, p. 64 .

${ }^{*}$ It will facilitate the determination to pull out one of the feathers. 
[1. Cepphus mandtii (Licht.) Newt.-Continued.]

1824. Uria glacialis Brenм, Lehrb. Vög. Eur., pp. 924, 1008.-Id., Isis, 1826, p. 985.-FABER, Isis, 1827, p. 637.-Nilsson, Skand. Faun. Fogl. 3 ed. ii, p. 554.-Cepphus g. Brehm, Handb. Vög. Deutschl., p. 991 (1831).

1824. Uria meisneri BRенм, Lehrb. Vög. Eur., p. 1006.—Id., Isis, 1826, p. 985.— FABER, Isis, 1827, pp. 637, 638.

1839. Uria mandstii Lesson, Rev. Zool., 1839, p. 46 (err. typ.).

1844. Uria grylle mandtii Schlegel, Rev. Crit., p. cvii.

1847. Uria grylle var. glacialis Sundev., Vłg. Seandin. Atl. Livr. iv, pl. - Id., Öfv. Sv. Vet. Akad. Handl., 1863, p. 126.-Id., ibid., 1874, No. 3, p. 22.Malmgren, Öfv. Sv. Vet. Akad. Handi. 1864, p. 403.-Id., J. f. Orn., 1865, p. 261.-Palmén, Finl. Fogl., ii, p. 668 (1873).

\section{FIGURES.}

Dresser, B. of Eur., pt. lxiii and lxiv, pl. -.

Voy. Scandin. Atlas, livr. iv, pl. - .

Audubon, B. of Amer. vii, pl. cecclxxiv.

Reichenb., Natat., pl. iv, fig. 46.

2. Cepphus grylle (Lin.) Flem.

1758:-Alca grylle Lin., Syst. Nat., 10 ed. i, p. 130.-Schleg., Mus. P. B. Urinat., p. 17 (1867).-Colymbus g. Lin., Syst. Nat., 12 ed., i, p. 220.Uria g. BrÜnn., Orn. Bor., p. 28 (1764).-FABER, Isis, 1827, p. 635.-MACGILl., Hist. Brit. B., v, p. 331 (1852).-Nilsson, Skand. Faun. Fogl., 3 ed., ii, p. 550 (1858).-DEGL. \& GERBE, Orn. Europ., ii, p. 603 (1867).-BRANDT, Mél. Biol., vii, 1869, p. 207.-PaLmén, Finl. Fogl., ii, p. 666 (1873).-KJÆRBöll, Danm. Fugl., 2 ed., p. 736 (1877).-Finsch, $2^{\text {te }}$ Deutsch. N. Polfahrt, ii, p. 221 (1874).-Dresser, B. of Eur., pt. lxiii, lxiv, (18 ).-FlemING, Brit. Anim. (p. 142) (1828).-Cepphus g. Brenm, Handb.Vög. Deutschl., p. 987 (1831).-Naumann, Naturg. Vög. Deutschl., xii, p. 461 (1844).Newton, Ibis, 1865, p. 519.-Collett, Christ. Vid. Selsk. Forh., 1868, sep., p. 78.

1764.-Uria grylloides BRÜnn., Orn. Bor., p. 28.

1764.-Uria balthica BRünn., Orn, Bor., p. 28.

1817.-Uria leucoptera Vienllot, Nouv. Dict. d'Hist. N., xiv. p. 35.

1819. - ? Grylle scapularis Leach, Thoms. Ann. Philos., xiii (p.60).

1824.-Uria arctica BReHм, Lehrb. Eur. Vög., p. 988.

1831.-Cephus faroeensis BREHм, Handb. Vög. Deutschl., p. 990.

1840.-Uria grœnlandica GRAY, List. Gen. B. (p. 98).

\section{FIGURES.}

Naumann, Naturg. Vög. Deutschl., xii, pl. 330.

Gould, B. Eur. (pl. 399)._Id., B. Gr. Brit., v (pl. 49).

Baird, B. N. Amer., pl. xevi, fig. 2.

\section{Cepphus columba PaLL.}

1790.-Uria grylle $\beta$. Latinam, Ind. Orn., ii, p. 797.

1826.-Cepphus columba Pallas, Zoogr. Ross. As., ii, p. 348 (part).-Dria 6. Keys. \& Blas., Wirbelth. Eur., p. xcii (1840).-Cassin, U. S. Expl. Exp., Orn., p. 346 (1858).—Id., in Baird's B. N. Amer., p. 912 (1858).-Id., Pr. Philada. Acud., 1862, p. 323.-Heermann, Pac. R. R. Rep., x, Birds (p. 
[3. Cepphus columba PaLL.-Continued.]

76) (1859).-Suckley, Pac. R. R. Rep., xii, pt. ii, p. 285 (1860).-Coues, Pr. Philada. Acad., 1868, Sep., p. 72.-Dall \& Bannist., Tr.Chicag. Acad., i, 1869, p. 309.-Brandt, Mél. Biol., vii, 1869, p. 207.-Finsch, $\Lambda$ bh. Brem. Ver., iii, 1872, p. 78.-Dall, Avif. Aleut. Isl., Unal., eastw., p. 11 (1873).-Id., Avif. Aleut. Isl., west Unal., p. 10 (1874)._Taczan., Bull. Soc. Zool. France, 1877, p. 51.-Id., ibid, 1883, p. 398.-Blakist. and Pryer, Tr. As. Soc. Jap., x, 1882, p. 91.-Bean, Pr. U. S. Nat. Mus., 1882, p. 172.Nelson, Cruise Corwin, p. 117 (1883).-Hartlaub, J.f. Orn., 1883, p. 285. 1832,-_Uria grylle Kittuitz, Isis, 1832, p 1105 (nec Lin.).-Id., Denkw. Reise, i, pp. 273, 291.-?Cepphus g. Whitely, Ibis, 1867, p. 210.

\section{FIGURES.}

Voy. Vincennes and Peacock, Orn. Atlas, pl. 38, fig. 1. Baird, B. N. Amer., pl. xevi, fig. 1.

\section{Cepphus carbo Pall.}

1826.-Cepphus carbo Pallas, Zoogr. Ross. As. ii p. 350.-Newton, Ibis, 1865, p. 519.-Uriac. Brandt, Bull., Scientif. ii, 1837, p. 346.-Id., Mél. Biol., vii, 1869, p. 206.-Middend., Sibir. Reis. ii, 2 (p. 239) (1853).-SCHRENCK, Reis. Amurl. i, p. 496 (1860).-Cassin, Pr. Philada. Acad., 1862, p. 323.-Coues, Pr. Philada. Acad., 1868, Sep. p. 73.-TAcZan., Bull. Soc. Zool. France, 1877, p. 51.-Blakist. and Pryer, Tr. As. Soc. Japan., x, 1882, p. 90.Alca c. Schlegel, Mus. P. B. Urinat., p. 17 (1867).

\section{FIGURES.}

Gould, B. Asia, pl. - .

Middend., Sibir. Reis. ii, 2 (pl. xxiii, fig. 6).

Reichenb., Natatores, pl. ccclxxv, figs. 2937-39.

Baird, B. N. Amer. pl. xevii.

\section{Cepphus motzfeldi (Benick.) SteJn.}

1824.-Uria motzfeldi BenICKen, Isis, 1824, p. 889.

1824.-Uria unicolor FABER, Isis, 1824, p. 981.-BREHM, Isis, 1826, p. 988.1d., Handb. Vög. Deutschl., p. 985 (1831)._Schlegel, Rev. Crit., p. 106 (1844).-Bonap., Compt. Rend., xlii, 1856, p. 774.-Id., Catal. Parzud., p. $12(1856)$.

1842.- "Grylle carbo Brandt" Bp., Cat. Met. Uec. Eur., p. 82, (ex Bor. Eur. or. As.) (part. nec PALl., nec BrandT).- "Uria carbo Brit. Mus. ex Iceland," Newton, Ibis, 1865, p. 518.

1867.-Alca grylle Schlegel, Mus. P. B. Urinat., p. 20, (part) n. 27.-Uria g. Kumlien, Bull. U. S. Nat. Mus. 15, p. 104 (part).

(NO FIGURE.)

\section{Smithsonian Institution,}

Washington, D. C., June 15, 1884. 


\section{$2 \mathrm{BHL}$ Biodiversity Heritage Library}

Stejneger, Leonhard. 1884. "Remarks on the species of the genus Cepphus." Proceedings of the United States National Museum 7(425), 210-229. https://doi.org/10.5479/si.00963801.7-425.210.

View This Item Online: https://www.biodiversitylibrary.org/item/31798

DOI: https://doi.org/10.5479/si.00963801.7-425.210

Permalink: https://www.biodiversitylibrary.org/partpdf/11558

\section{Holding Institution}

Smithsonian Libraries

\section{Sponsored by}

Smithsonian

\section{Copyright \& Reuse}

Copyright Status: NOT_IN_COPYRIGHT

This document was created from content at the Biodiversity Heritage Library, the world's largest open access digital library for biodiversity literature and archives. Visit BHL at https://www.biodiversitylibrary.org. 